\title{
Record Attendance at the 10th EURETINA Congress in Paris
}

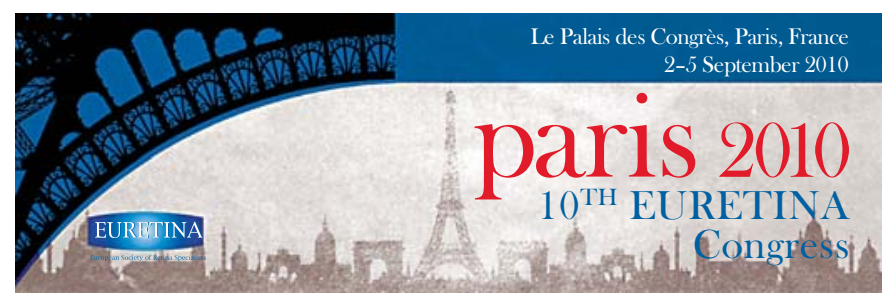

A record number of medical and surgical retina specialists from all over the world converged on Paris this month to attend the 10th EURETINA Congress, which took place from the 2nd to the 5th September in the Palais des Congrès, Porte Maillot. A total of 2,700 delegates attended the Congress, making it not only the largest EURETINA meeting in the history of the Society, but also establishing it as the largest retina meeting ever convened.

The 2010 Congress also saw EURETINA partner with the European Society of Cataract and Refractive Surgeons (ESCRS), drawing a total number of almost 9,000 ophthalmologists to the Palais des Congrès over a 6-day period. Addressing the audience at the official opening ceremony, EURETINA President Bill Aylward welcomed delegates to Paris for what he expected would prove to be the most stimulating and rewarding congress to date: 'It is truly a great pleasure to welcome all of you to this wonderful city for the 10th EURETINA Congress. We are particularly excited as this is the first time that we have joined forces with the ESCRS for this joint meeting. The early signs of this collaboration are very good.'

At the core of the EURETINA programme were 13 main sessions, comprising presentations from invited speakers, all of whom are leaders in their field. There were also a total of 32 Instructional Courses and Surgical Skills Courses, the former including the daylong Retinal Detachment and Uveitis Courses. Two combined EURETI-
NA/ESCRS Symposia and one Clinical Research Symposium anchored the meeting.

Other new introductions for 2010 were the French-British and Eire Symposium (CFSR-BEAVRS) and the ARVO symposium on anti-VEGF therapy beyond AMD. The programme also included popular scientific contributions such as the Amsterdam Retina Debate, Eurolam, the Fan Club and the French-Israeli (AFIV SOFI) Symposium.

The EURETINA Lecture 2010 was given by Prof. Anthony Moore, Moorfields Eye Hospital, London, who discussed the current state of research into retinovascular disorders of childhood. Dr. Martine Jager was the recipient of the Kreissig Award and made the presentation entitled 'Immunology in uveal melanoma: friend or foe?'

Not only did the 10th Congress see an increase in attendance, but abstract submission numbers also showed a dramatic increase from previous years. Free paper submissions increased by $30 \%$ from the Nice 2009 Congress, while video submissions doubled since last year. While stressing that the organizing committee was extremely gratified in the record attendance and progress displayed in Paris this year, Bill Aylward said that the goal of EURETINA in the years ahead would be to continue to make progress and raise standards: 'We don't just want to be big - we also want to be the best.'

The 11th EURETINA Congress will take place in the Queen Elizabeth II Centre in London from the 26th to the 29th May 2011.

\section{KARGER}

Fax +41613061234 E-Mail karger@karger.ch www.karger.com
(C) 2011 S. Karger AG, Basel

0030-3755/11/2253-0186\$38.00/0

Accessible online at:

www.karger.com/oph 